nearing completion. More than $\mathbf{1 5 2 0}$ was spent purchasing and transporting animals like penguins, sea-lion, wolves, wallabies and laughing jackass; but owing to various restrictions some valuable animals offered could not be accepted. The meeting was followed by a lecture by Father P. J. Kennedy, a well-known local ornithologist, on the birds of Phœnix Park. Father Kennedy gave a detailed history of the formation of the Park until it was turned into a bird sanctuary in 1937, its trees, shrubs, lakes and ponds being so valuable. The birds he then discussed were the 83 species which have been observed in the Park, and included grey crow, rook, jackdaw, magpie, jay, starling, greenfinch, goldfinch (which he said is increasing), chaffinch, bullfinch, linnet, crossbill, yellow-hammer, skylark, pied wagtail, tree-creeper, black-cap and spotted fly-catcher.

\section{The Maidenhair Tree}

THE origin of the curious generic name, Ginkgo biloba, of this tree is very fully discussed, with reference to original Chinese and Japanese descriptions, by Prof. A. C. Moule in T'Oung Pao, 23, published by the firm of E.J. Brill, Leyden. The name seems to be due to Engelbert Kaempfer, a German naturalist (1651-1716) who was in Japan apparently about 1690-2. The Kaempfer MSS. are stated by Larousse to be preserved in the Museum of Botany at Leyden where, however, search has failed to find them; Prof. Moule, however, through Sir Albert Seward, has traced the original entries of Kaempfer in his manuscripts in the British Museum. These seem to make it clear that when Kaempfer, some eighteen years later, published the names from his original descriptions, he deciphered incorrectly an original manuscript entry of Sankyo in the form of Ginkgo, where it is difficult to decide whether the ' $g$ ' is a slip in transcription or a misprint that has been overlooked. Thus "this strange word, which is unpronounceable and probably ought never to have existed, has been for nearly two centuries and, I suppose, will always be the generic name of this beautiful and interesting tree". There is a very full discussion of the numerous Chinese names of this tree which are all either descriptive names of two or more words or are frankly borrowed from other trees, suggesting that the tree was not known in northern China during the centuries when the Chinese classical civilization and language were being formed. This may confirm the view of $F$. N. Meyer and others that the tree is indigenous in the forests of Chê-Chiang, but in favour of the other view that it survives only in cultivation is the fact that no large specimens have been reported from forests. There is an interesting discussion of its fire-resisting qualities, which were exemplified by the recovery of many trees in Tokyo after the big fire that followed the earthquake in 1923 ; popular testimony thus made a huge Ginkgo tree largely responsible for the survival of the great temple of Kwannon at Asakasa; it was believed that the tree literally rained moisture on the roof, and also protected it against burning fragments carried in the wind.

\section{Health Committee of the League of Nations}

Ar the twenty-fifth session of the Health Committee of the League of Nations, April 26-May 1 (G. Allen and Unwin, League of Nations Department, 40 Museum St., Iondon, W.C.I : Report to the Council on the Work of the 25th Session of the Health Committee, 1s.) the next three-year programme was discussed and approved. Among the permanent activities of the Committee, its work on biological standards is far from being completed. New therapeutic agents gain acceptance with the advance of science and require assay in terms of some common standard, and other standards already adopted are either open to improvement or, being composite, are liable to be replaced sooner or later by the active substance in pure form, apart from the possibility of physical or chemical methods replacing the biological method. Forty-one countries have adopted or are about to adopt the international standards recommended by the Permanent Com. mission on Biological Standards, and thirty-one Governments have established or are about to establish national centres, thus simplifying the task of the central institutes at Copenhagen and Hamp. stead. For drugs like digitalis, pituitary extract and arsphenamine, no insuperable difficulties are anticipated in preparing national standards, but it is expected that for serological standards the Copenhagen Institute will have to continue to supply international standard sera to most of the national centres. The standardization of anti-anthrax serum, examined in 1925, requires further investigation in collaboration with the Institute at Budapest and Bucharest. Further study of the standardization of anti-swineerysipelas serum is also necessary as well as con. sideration of changes in the international standards for tuberculin and staphylococcus anti-toxin. The standardization of anti-snake venom sera, pharmacological standards, as well as those for vitamins and sex hormones, also fall within the next three-year programme of the Commission. Other matters in the programme of the Committee are leprosy, rural hygiene, housing, physical education, nutrition and opium and other dangerous drugs.

\section{Dietetics and Social Problems}

THE problem to what extent a wise social policy, taking into account modern scientific developments in the field of nutrition, can help to raise the standard of living in certain countries, or for certain categories of population, which at present suffer from undernourishment or malnutrition, is being investigated by the International Labour Office, assisted by a Committee of Experts which met at Geneva on April 9-10, under the chairmanship of Mr. Bramsnaes. This committee discussed the efforts of the International Labour Office to demonstrate the progress of dietetic science and its importance in regard to social questions. Special stress was laid on the necessity of distinguishing between the physiological, health and social aspects of the problem, and it was agreed that the studies should be studied simultaneously in various countries according to a uniform 
plan which would assist international co-ordination of comparative results. The projected investigations are aimed at determining the relation between nutritional requirements and different occupations, the economic and social effects of different policies of improving the standard of nutrition of workers and their families, and at defining the principles on which the regulation of wages, where it exists, is based and methods of fixing benefits under social insurance or assistance schemes. Other studies will deal with the nutrition of apprentices and young persons and of the unemployed, etc.

\section{Rural Electrification}

Ar the present time many people are interested in the supply of electricity for thinly populated districts, but they are only beginning to realize that it is a very safe commercial venture. There is a great demand for an electric supply at a reasonable cost and the expense of advertising by demonstration vans, etc., is not great. In a paper on this subject read by J. S. Pickles to the Institution of Electrical Engineers on December 2 it is pointed out that in many countries abroad the public supply of electricity is regarded as a necessity. As a practical example of what can be done by borough councils, he gives a description of the Dumfries scheme, which covers the whole of a geographical county of 1,070 square miles in area. With the exception of only one town, no electrical development had previously taken place in the supply area. The scheme was begun six years ago, the electric supply being purchased by the borough from the Central Electricity Board. The policy adopted aimed at providing supply to every consumer without asking him to make a contribution towards the capital cost, no matter what was the length of his necessary service main. Neither was he asked to pay any guaranteed minimum revenue. The adopted scheme provided for the immediate erection of a comprehensive system of overhead wires with the necessary transformers, etc., capable of giving a supply practically to all prospective consumers within the area. It was recognized that the expenditure of large capital sums in the early years would lead to commercial deficits unless the development amongst consumers was very rapid.

THERE is an assisted wiring scheme extending over five years for the consumer and no initial pay. ments of any kind are required. A two-part tariff is usually adopted. The consumer pays $\frac{3}{4} d$. per unit for running costs and 5 shillings per room per quarter, no charge being made for sculleries, bath rooms, boxrooms, etc., and 20 is the maximum number of rooms for which a charge is made. A radiator can be hired for 1s. 6d. per quarter and a wash boiler for $2 s .6 d$. A two-part tariff meter has been adopted, which collects both the fixed and the running charges. Very few of the consumers go for long holidays, and so the supply is never cut off for long periods. As many of the consumers have 'all-mains' wireless sets they never allow their supply to be cut off for long. During the first five years of working the scheme there have been small deficits in the year's working, but it is estimated that from the sixth year onwards there will be a profit. Doubtless later on there will be a reduction in the consumer's charges, as the demand seems constantly increasing.

\section{The Modern Quarterly}

WE welcome the first number of the Modern Quarterly (offices : 2 Parton Street, London, W.C.1), because throughout it proclaims the supreme importance and the social function of science in the contemporary world. But we must add a qualifying regret that it appears both from its contents and the personnel of its editorial council to be inclined to identify the progress of science with one form of the organization of society and especially of industry. This must prejudice many readers against the suggestive ideas and generally high aims of the promotors. Must we accept Marx, Lenin and Russia, it will be asked, as the gospel and best exemplification of science in society ? Are not the more liberal, though more slowly moving societies, like our own, perhaps doing the work of human evolution even more effectively in the long run, certainly without the bitterness and the bloodshed of the revolutionary method ? But these are large questions impossible to discuss in a note. Of the articles in this number, two should be especially mentioned: the first, by Prof. H. Levy, acutely criticizing the mechanistic explanation of the universe, and the fourth, by Dr. Joseph Needham (the bulk of his Herbert Spencer Lecture at Oxford), in which he attempts a revaluation of Spencer's presentation of the idea of progress. This is the most valuable part of this first number and deserves careful study, none the less because it contains conspicuous examples of the communistic doctrines referred to above. Mr. Max Black has an article carefully considering and criticizing the doctrines of Wittgenstein and the logical Positivists. It is rather a remarkable feat to be able to write a complete, though short, account of "The Evolution of Positivism" (including the nineteenth century) without even mentioning the man who first systematized that way of thinking and gave it its name.

\section{Earthquake in the East Indies}

ONE of the greatest earthquakes for several months past occurred on February 1. The first movements were recorded at Kew at 7 h. 19 m. 52 s., p.m., and the largest oscillation about three-quarters of an hour later. According to Mr. J. J. Shaw, it was a very deep-seated earthquake. The records at Kew and Bombay show that the distances of the origin from these two places are respectively 8,250 and 4,250 miles. Thus, the earthquake occurred in the Banda Sea in about lat. $5^{\circ} \mathrm{S}$., long. $130^{\circ} \mathrm{E}$., at 7.5 p.m., G.M.T. (February 2, 1.45 a.m., local time). Three earthquakes, with a focal depth of about 260 miles, occurred close to the spot indicated (in lat. $5.5^{\circ} \mathrm{S} . \mathrm{g}^{\circ} 130^{\circ} \mathrm{E}$.) on May 10,1920 , and March 23 and 24, 1921; while two others, with the same focal depth, originated in a centre lying five degrees to the east on October 10, 1921, and February 19, 1923. 